\title{
LEEDU DRAAMA RETSEPTSIOON EESTIS
}

\author{
Anneli Saro \\ Tartu Ülikool
}

\begin{abstract}
Ülevaade. Eesti teatril on ajaloolises plaanis kõige tihedamad sidemed olnud saksaja venekeelse ning angloameerika kultuuriruumiga, kuid sidemed lõunapoolsete lähinaabritega on olnud üsna sporaadilised. Käesolev uurimus käsitleb Leedu draama vastuvõttu Eestis ja Eesti teatris. Artikli eesmärgiks on (1) anda statistiline ajalooline ülevaade Eestis ilmunud ja lavastatud Leedu näitekirjandusest ning (2) uurida Leedu draama retseptsiooni Eestis, tuginedes näidendite lähilugemisele, audio- ja videosalvestustele ja ilmunud kriitikale ning tõlgendades nimetatud allikaid Eesti kultuurikontekstist lähtuvalt.
\end{abstract}

Märksõnad: Leedu draama, eesti teater, retseptsioon, Eesti-Leedu kultuurisuhted

DOI: https://doi.org/10.12697/jeful.2017.8.1.12

\section{Sissejuhatus}

Eri maade kultuuri-, sh teatrisuhete uurimine on kultuuriteadustes üsna traditsiooniline valdkond. Selle väite näiteks võib tuua Karin Kase raamatu "Shakespeare Eesti teatris" (1964), Lea Tormise "Teatrisuhted üle idapiiri. Eesti teatri sidemetest nõukogude teatriga 1920-1940" (1973) või Kristel Pappeli uurimused Eesti teatri suhetest saksakeelse kultuuriruumiga 19. sajandil (nt Pappel 2003, Gerlach, Liivrand ja Pappel 2016) ning lisaks neile veel mitmeid bakalaureuse- ja magistritöid. Eesti teatril on ajaloolises plaanis kõige tihedamad sidemed olnud saksakeelse (19. sajand ja 20. sajandi esimene pool), venekeelse (20. sajand, eriti selle teine pool) ning angloameerika (1990. aastatest alates) kultuuriruumiga. Enim tähelepanu on Eesti teatriuurimuses pälvinud teatrisuhted ida- ja põhjapoolse lähinaabriga, kuid ka Saksamaa ja Austria saksakeelse kultuuriruumiga. Kultuuriteadustes on see üsna tüüpiline, et kultuurisuhteid uuritakse enamasti just mõne suurema (nii geograafiliselt kui ka sümboolselt kapitalilt) riigiga. See tendents saab kinnitust ka artikli kontekstis, sest uurimuslikus plaanis pole Eesti teatri sidemed lõunapoolse lähinaabri Lätiga väga palju tähelepanu 
pälvinud, Leedu-Eesti teatrisuhetest rääkimata. Käesolev artikkel, mis käsitleb Leedu draama vastuvõttu Eestis ja Eesti teatris, sündis paljuski kui austusavaldus suurele teatrisõbrale ja Leedu Vabariigi aukonsulile Eestis - professor Birute Klaas-Langile.

Artikli eesmärgiks on (1) anda statistiline ajalooline ülevaade Eestis ilmunud ja lavastatud leedu näitekirjandusest ${ }^{1}$ ning (2) uurida Leedu draama retseptsiooni Eestis, tuginedes näidendite lähilugemisele, audioja videosalvestustele ja ilmunud kriitikale ning tõlgendades nimetatud allikaid Eesti kultuurikontekstist lähtuvalt. Terminit retseptsioon mõistetakse siin avaralt, s.t pidades silmas nii teose passiivset vastuvõttu kui ka aktiivset kaasa- ja ümberloomist, seetõttu mahuvad ühe mõiste alla nii tõlkijate, lavastajate, näitlejate, kunstnike jt loov töö kui ka lugejate-vaatajate mentaalne tõlgenduslik tegevus. (Vt lähemalt Saro 2004: 23-39)

\section{Uurimuse kontekst ja struktuur}

"Erinevalt Põhjamaade vahelisest ühisele ajaloole ja pikaajalistele traditsioonidele tuginevast piirkondlikust ühtsustundest on Eesti, Läti ja Leedu lähiajaloos keskset rolli omanud samasugune tundmus suuresti kujuteldavat laadi. Balti ühtsustunde näol on tegemist eelkõige veendumusega, mis ilmneb kolme rahva ajaloo keerukamatel hetkedel, seejärel taas kadudes" (Rämmer 2016: 9). Algo Rämmeri 1920.-1930. aastate Balti riikide kultuurikoostööd käsitlevast doktoritööst ilmneb, et kuigi mitmesuguste ameti- ja erialaorganisatsioonide ühistegevus muutus iseseisvuse ülesehitamise perioodil järjest tihedamaks, siis kunstialade esindajate koostöö jalgu alla ei saanud - nii jäid ka ära mitu Eesti, Läti ja Leedu teatritegelaste planeeritud kokkusaamist (ibid.: 78). Peamiste takistustena nimetab Rämmer siin ühiste eesmärkide puudumist ja kunstialase koostöö kulukust, kuid toob laiemas kontekstis esile ka ideoloogiliselt problemaatilise ühiskeele küsimuse: nimelt kasutati lingua franca'na parema puudumisel vene ja saksa keelt.

Keeleoskus on mänginud strateegilist rolli ka teatrisuhete kujunemisel. Kuni 1920. aastateni tõlgiti lavale jõudnud näitekirjandust valdavalt saksa ja vene keelest, sh ka teistes keeltes kirjutatud draamat, sest

1 Eesti keelde on tõlgitud mõnevõrra rohkem leedu näidendeid, kui artiklis käsitletud. Avalikkuse ette mittejõudnud tekstid on kõrvale jäetud artikli mahtu silmas pidades, kuid infot nende kohta leiab Eesti Teatri Agentuuri näidendite andmebaasist. 
kahe nimetatud keele oskus oli Eestis laialt levinud. Hiljem eri keelte oskajate diapasoon laienes ning tõlkima hakati rohkem originaalkeeltest.

Uurides Eesti teatrite repertuaari avaldatud nimekirjade põhjal (Kuidas päikest... 1974: 59-67, Tormis 1978: 407-485, Kask 1987: 539-557), ei torka selles kuni 1950. aastate keskpaigani näitekirjanike hulgas silma ühtki leedu nime. Välistada ei saa muidugi juhtumeid, et mõnel leedu keeles kirjutaval kirjanikul võib olla ka vene- või saksapärane nimi, kuigi see ei ole väga tõenäoline.

Ootuspäraselt hakati 1950. aastail Eesti teatrites süstemaatilisemalt lavastama ka leedu näidendeid, sest need kuulusid nn vennasrahvaste dramaturgiana kohustuslikku repertuaari. Nimelt kehtis Nõukogude Liidus teatritele kirjutamata reegel, et vähemalt üks kolmandik repertuaarist pidi põhinema nõukogude (vene või vennasrahvaste) autorite tekstidel. Lavale jõudsid nt Juozas Grušase ja Kazys Saja teosed, mida analüüsitakse hiljem põhjalikumalt, kuid ka selliste rahvusvaheliselt vähem tuntud autorite nagu Viktoras Miliūnase ja Regina Mikalauskaitè tekstid.

Viktoras Miliūnaselt (1916-1986) on eesti keeles ilmunud näidend "Allamäge" (1955) ning lavale jõudnud teos "Kajakad saadavad" (1962, lav Karl Ader, tlk Voldemar Metsamärt, Ugala). "Kajakad saadavad" - näidend kolhoosi kaluri Jonis Kalvise² (Heino Raudsik) heitlikust isiksuslikust kasvamisest ja ühiskonda sulandumisest kriitikutele ja publikule erilist muljet ei jätnud, sest nii peategelase kui ka teda ümbritseva kolhoosirahva ideoloogiline ja psühholoogiline profiil jäid arusaamatuks ning seepärast tegelased laval ebaveenvaks. Regina Mikalauskaitè "Pruut" (Sužadetine ehk Kai taves laukia, tlk Mihkel Loodus) esietendus 1963. aastal Rakvere teatris (lav Aime Kala-Kokovkina) ning selle põhjal valmis järgmisel aastal samanimeline kuuldemäng, mis on kuulatav Eesti Rahvusringhäälingu arhiivis. Mikalauskaite näidend illustreerib, kuidas nõukogude ühiskond ühelt poolt püüab toetada ja teiselt poolt pärsib positiivsete töölisnoorte üleskasvamist ning arengut. Üsna tüüpiliselt nõukogude näidenditele on kõige positiivsem tegelane noor rikkumata moraali ja otsingulise vaimuga naine Alge (Siina Üksküla), kes aitab amoraalsele keskkonnale vaatamata ausaks kodanikuks ümber kasvada kriminaalse taustaga Vytasel (Aarne Üksküla). Sellise temaatika ja etteaimatava süžeega näidendeid võib nimetada ajastukohasteks tarbetekstideks, millel pole vastuvõtuahelas pikka iga.

2 Kõik tegelaste nimed on artiklis esitatud eesti keeles levinud transkriptsioonis. 
Huvi lõunanaabrite draama ja teatri vastu suurendas ka aastail 1956-1958 toimunud "Balti teatrikevade" festival. Aastal 1961 andis Tallinnas külalisetendusi Leedu NSV Riiklik Akadeemiline Draamateater ning Vilniuses V. Kingissepa nimeline Tallinna Riiklik Akadeemiline Draamateater. Need sündmused panid aluse Eesti ja Leedu teatrisuhete tekkimisele ja arenemisele 1950.-1980. aastail.

Tihedaid teatrikontakte nende maade vahel siiski ei tekkinud. Analüüsides Eesti teatrite mängukava aastail 1965-1985, nendib Luule Epner: "Läti ja leedu dramaturgia panus repertuaari ei olnud eriti suur (kokku veerandsaja lavastuse ümber) ning kaldus lätlaste kasuks, seda eelkõige läti klassika arvel. [...] Leedu kirjanduse retseptsioonis oli seevastu kaalukauss kaasaegse dramaturgia kasuks." (Eesti sõnateater... 2015: 205) Seejärel mainib ta olulisemaid Kazys Saja näidendite lavastusi ning ebaõnnestunud katset teha kuulsast leedu filmist "Keegi ei tahtnud surra" (stsenarist Vytautas Žalakevičius) teatrivariant (1977). Samas Raimundas Samulevičiuse 12 stseeni lauludega "Sild kaugesse öösse" (Tiltas $\dot{i}$ tolimaja nakti, tlk Mihkel Loodus, 1969, lav Vello Rummo, Pärnu draamateater) ning Saulius Šaltenise ja Leonidas Jacinevičiuse muusikal "Armastus... (Tulepüüdjad)" (Ugnies medžiokle su varovais, tlk Mihkel Loodus, 1976, lav Aivo Paljasmaa, Rakvere teater) osutusid mõlemad üsna publikumenukaks ning pakkusid ka näitlejaile tänuväärset tööd: ENSV Teatriühing premeeris esimese lavastuse osatäitjat Arnold Sikkelit ja teises Tõnu Karki.

Perioodil 1986-2016 jõudsid Eesti lavadele ainult üksikud Leeduga seotud teosed: Kazys Saja "Hei, pöialpoisid!" (1985-1988, 27 osa, lav Uno Leies, ETV), Anatoli Šenderovi muusikal põhinev ballett "Maria Stuart" (1988, lav Ülo Vilimaa, Vanemuine), Marcelijus Martinaitise "Tuhapart" (1989, lav Algirdas Mikutis, Nukuteater), Antanas Gudelise "Nukumängulugu" (1999, lav Rimantas Driežis, Nukuteater) ja Sigitas Parulskise "Metsnaine" (2007, lav Kostas Smoriginas, ööklubi Papillon). Torkab silma, et kolm neist on lastelavastused ning kolme teose lavastajad on leedukad, s.t ilmselt on teksti nendel juhtudel Eestisse toonud lavastaja. Sellest nimekirjast tuleks esile tõsta menukat ja mõjukat telelavastust "Hei, pöialpoisid!", mille stsenaariumi ja laulutekstid oli Kazys Saja raamatu "Hei, pugege peitu. Kellele muinasjutt, kellele tõsilugu ehk kaheosaline jutustus lastest ja pöialpoistest" ainetel kirjutanud Eve Viilup. Raamat oli Valvi Strikaitienė tõlkes ilmunud aastal 1973, teine trükk 1977 kirjastuses Eesti Raamat.

Eelnevast juba nähtub, et pärast Eesti ja Leedu iseseisvumist muutusid teatrikontaktid üsna juhuslikuks. Aastail 1984-1992 toimunud, taaselustatud festivali "Balti teatrikevad" traditsioon katkes: "Järgmine 
korraldaja Leedu jättis festivali tegemata ja sünnitas peagi rahvusvahelise teatrifestivali "Life", kuhu mitte kordagi ei kutsutud ühtegi eesti teatrit, milles võib näha ka Balti festivalil lõõmanud "sõpruse" tagajärge" (Allik 2006). Vaatamata sellele võis Eestis toimuval teatrifestivalil Baltoscandal just 1990ndatel näha mitme leedu noorema põlvkonna lavastaja (Oskaras Koršunovase, Gintaras Varnase jt) töid ning 21. sajandil andis Eestis paaril korral külalisetendusi ka rahvusvahelise kuulsusega lavastaja Eimuntas Nekrošiuse trupp Meno Fortas ("Othello", 2003, "Kirsiaed", 2008).

Pärast seda, kui nii Leedu kui ka Eesti lavastajad olid osa saanud rahvusvahelisest kogemusest ja menust, tekkis taas huvi Balti naabrite käekäigu vastu ning üheks märgiks sellest oli ka Balti teatri festivali järjekordne taaselustamine aastal 2005. Eesti teatrielus kujunes vaieldamatuks suursündmuseks aga Marius Ivaškevičiuse näidendi "Väljaheitmine. Ühe õuna kroonika" lavastamine Eesti Draamateatris 2016. aastal. Ivaškevičiuse ja selle näidendi positsioon Leedu kultuurimaastikul ning Eesti-lavastuse sündmuslikkus annavad hea põhjuse "Väljaheitmist" hiljem põhjalikumalt tutvustada. Seega näivad EestiLeedu teatrisuhted olevat tõusulainel.

Järgnevalt tutvustatakse Eestis elavamat vastukaja leidnud Leedu autorite teoseid ning nende tõlgendusi teatrilaval ja kriitikas.

\section{Juozas Grušas (1901-1986)}

Juozas Grušas, olles saavutanud juba teatava menu oma novellide ja romaanidega, hakkas näidendeid kirjutama alles pärast teist maailmasõda, kuid kujunes siis väga produktiivseks ja tunnustatud dramaturgiks ning seda eelkõige oma isamaalisi tundeid õhutavate näidenditega. Valik tema näidendeid - "Adomas Brunza saladus", "Armastus, džäss ja kurat", "Soome saun" ning "Herkus Mantas" - on ilmunud kogumikus "Näidendid" (1987, tlk Mihkel Loodus).

Leedu teatri ajaloos kujunes murranguliseks Grušase ajalooline näidend "Herkus Mantas" (1957). See on Peter von Dusburgi kroonikal "Chronicon terrae Prussiae" põhinev ajalooaineline tragöödia 13. sajandil preislaste ülestõusu juhtinud Herkus Mantasest, kes oli üles kasvatatud kristlasena, kuid pöördus täiskasvanuna tagasi loodusjumalate poole, kuni kaaslaste julmus sundis teda lahti ütlema ka neist. "Teie jumalate varjus tuhmub päike ja sureb mõte" (Grušas 1987: 298). Eestis näidendit lavastatud ei ole. 
Näidendit "Pulma-aastapäev" (Vedybu sukaktis, 1958) mängiti pealkirjaga "Perekondlik pidu" (1959, lav Laine Vaga) Ugalas. Kui jutustada ümber selle süžee, siis võib jääda mulje, et tegemist on üsna tüüpilise korruptsiooni paljastava ühiskonnakriitilise teosega, millesarnaseid kirjutati nii Nõukogude Liidus kui ka idablokis massiliselt. Põnevust ja pinget lisavad loole aga mõned väiksed vormilised, võiks öelda, et ibsenlikud nüansid, kuigi just seda peeti kriitikas teose nõrkuseks (nt Tamm 1960). Viis aastat süütult vangis viibinud endine üliõpilane Andrius (Lembit Õunroos) püüab paljastada oma venna, insener Tomas Merkise (Karl Liigand) süütegu - ehitusmaterjalide vargust ühiskondlike hoonete ehitustöödelt -, mille eest tema ise karistust kandis. Sellest tulenevalt minevikusündmusi mitte ei kujutata, vaid neid meenutatakse ja analüüsitakse. Kolmevaatuselise lavastuse vaatused katkestati poolelt sõnalt kõige põnevamas kohas, et neid siis pärast vaheaega samast kohast jätkata. Harjumuspärasest mustvalgest ideoloogilisest peajoonest erines "Perekondlik pidu" ka selle poolest, et paadunud kelmi Tomast kujutati kui väga intelligentset ja näiliselt rahulikku, oma õiguses veendunud inimest.

"Adomas Brunza saladus" (Adomo Brunzos paslaptis, 1966) esietendus 1966. aastal Rakvere teatris, lavastajaks Mai Mering. Sisuliselt kuulub see näidend nõukogude kirjanduses nii populaarse ja kohati isegi üleekspluateeritud teema alla nagu fašistide tekitatud kannatuste kirjeldamine ja fašismi kriitika. Kui Grušas oleks oma teose kirjutanud 1940.-1950. aastail, leiduks seal ehk rohkem ideoloogilist võitlust moraalselt heade ja halbade ning erinevatesse sotsiaalsetesse klassidesse kuuluvate tegelaste vahel, kuid 1960-ndaile omaselt ongi seegi näidend nii sisult kui ka vormilt palju ambivalentsem. Nimelt on teose peategelane skulptor Adomas Brunza sõja ajal gestaapo piinakambris reetnud oma sõbra, antifašistliku liikumise juhi Povilas Daugirdase ning seejärel järele andnud ihale sõbra naise Teresè vastu. Tegevus algab aastal 1965, kui Brunza ja Terese Saksamaal orvuna üles kasvanud poeg Rimas püüab jälile saada oma oletatava isa Daugirdase reetnud isikule ning samas arendab suhet Brunza uue naisega. Süžeelist põnevust hoiab seega üleval meestevaheline kassi-hiiremäng, kuid psühholoogilises plaanis domineerib emotsionaalseks Adomaseks ja ratsionaalseks Brunzaks lõhestunud peategelase sisekõne.

Näidendi "Armastus, džäss ja kurat” (Meilè, džiazas ir velnias, 1967) tõi 1969. aastal Ugalas lavale Aleks Sats, hiljem on see tekst olnud mitme harrastusteatri repertuaaris (nt 1986 J. Tombi nimelises Rahvateatris, 2008 SEE Teatris). Teos uurib kolme 1960-ndate põlv- 
konna noorukit: Andriust (Rein Malmsten), Juliust (Enn Kose) ja Lukast (Peeter Jürgens). Poiste iseloomustamiseks piisab faktist, et nad mängivad koos džässansamblis, sest džäss ja tango sümboliseerisid nõukogude ühiskonnas läänelike pahede kvintessentsi. Sergei Levin vihjas oma arvustuses koguni antisotsiaalsete ideoloogiate märkidele lavastuses, tuues näiteks hipi- ja lillelasteideoloogia koos fašismiga (Levin 1970). Tõsi, poisid katsetavadki lubatu ja lubamatu piire, nii et nende tegevusel on kohati selgelt kriminaalne taust. Seega ajastukontekstilt ja ideoloogialt sarnaneb Grušase näidend vägagi Egon Ranneti ülipopulaarse draamaga "Kriminaaltango" (1968), mille põhjal valmis Eesti Televisioonis 1981. aastal telelavastus "Kriminaaltango ja väga korralikud inimesed". Noori mehi püüab halvalt teelt tagasi ühiskonna rüppe tuua 17-aastane Beatriče (Leila Säälik), kellesse kõik kolm on armunud, kuid kelle nad lõpuks oma küünilisusega hukutavad. Huvi pakuvad just Beatriče sisekaemuslikud ja psühhoanalüütilised stseenid, mis rulluvad lahti pärast psüühilist šokki (I vaatuses päeviku avalikustamine, III vaatuses vägistamine). Sellest ansamblist tõstetigi kriitikas esile just Sääliku osatäitmist, mis triivis eemale ühekülgsest naiivsusest-positiivsusest ning mõjus oma psühholoogilise veenvuse ja mõtteselgusega.

Eestis pole lavale jõudnud ka Grušase "peaaegu absurdne tragikomöödia" "Soome saun" (Suomiška pirtis, 1984), mis kujutab nõukogude nomenklatuuri korrumpeerumist ja allakäiku ning kannab selgelt 1980. aastate ühiskonnakriitilise olmedraama esteetilist pitserit.

Kui leedu draama ja teatri ajalukku on jälje jätnud eelkõige Grušase ajaloo- ja isamaa-ainelised tekstid, nagu "Herkus Mantas" või "Barbora Radvilaite”" (Lithuanian Theatre 2009: 108, 121, 148), siis Eesti lavadele jõudsid need, mis tegelesid nõukogude ühiskonnas oluliste teemadega. Kuigi autor kasutab seal huvitavaid modernistlikke tehnikaid, on nendel näidenditel olnud Eestis teatud menu vaid väikelinnateatrites ning sedagi vaid üheks lavastuseks.

\section{Justinas Marcinkevičius (1930-2011)}

Justinas Marcinkevičiuse värssdraamad, mille mõju leedulaste rahvusliku eneseteadvuse tõusule ei saa alahinnata, on huvi pakkunud küll Eesti tõlkijatele ja kirjastustele, kuid mitte teatritegijatele. Nagu näitas juba Grušase dramaturgia retseptsioon ja mida kinnitavad ka Marcinkevičiuse teoste tõlked, siis Leedu ajalugu või selle 
taustal toimuvaid suhtedraamasid ei ole Eesti lavastajad pidanud piisavalt huvipakkuvaks. Takistuseks võis osutuda ka nende näidendite vorm - värss. Viljakas leedu kirjanduse tõlkija Mihkel Loodus on vahendanud eesti keelde Marcinkevičiuse Leedu kuulsusrikast ajalugu tutvustavate draamapoeemide triloogia "Mindaugas" (1968, ee 1988), "Katedraal" (Katedra, 1971, ee 1979) ja "Mažvydas" (1977, ee 1991). Lisaks sellele on Ilmar Vananurm tõlkijana avaldanud värssnäidendi "Heroica, ehk, Prometheuse hukkamõist" (Heroica arba Prometejo pasmerkimas, 1977, ee 1982), tõlgenduse kreeka mütoloogilise kangelase Prometheuse loost.

Marcinkevičiuse lähenemine Leedu ajaloole ei ole tavapärane, muistset vabadust ja kuningriiki heroiseeriv, vaid pigem problematiseeriv ja inimlikustav. "Mindaugases" tegelevad ajalookirjutuse probleemiga tegelased Must ja Valge kroonikakirjutaja. "Valge kroonikakirjutaja: "Jah, faktid! / Sind huvitab vaid fakt. Kuid inimene? / Mis sünnib inimestes? Mis neid vaevab? / Miks nad on rõõmsad? Miks nad kurvastavad? Miks põimunud on neis kõik sasikeraks, / mis hargneda ei taha? Aga faktid - neid lihvinud on ajaloo murdlained / kui lutsukive Neemeni jõe kaldal, / mis kõlbavad vaid lastel pilduda. / Ei, tuleb näha üldist. Inimest! / Ta tegude eesmärke, põhjusi."”' (Marcinkevičius 1988: 11) Kirjanik samastab end selles teoses Valge kroonikakirjutajaga, sest 13. sajandi ajaloosündmusi käsitletakse pigem kui diskursiivset konteksti Mindaugase siseelu kujutamiseks ja tema hingepiinade ajendit. Mindaugas pühendab kogu oma elu ühele ideele, Leedu kuningriigi loomisele ja laiendamisele, ohverdades selle nimel nii oma jumalad kui ka lähikondlased, kuid rahu ja õnne selle idee realiseerumine talle ei too, eesmärk abinõusid ei pühitse. Leedu esimene kuningas mõjub läbinisti hamletliku, eetilistest ja eksistentsiaalsetest kõhklustest vaevatud tegelasena ning seda paralleeli tugevdab ka värssteose lõpp - nii Mindaugase kui ka Valge kroonikakirjutaja mõrv.

Samasugune, siseheitlustest, eneseohverdusest ja palavast isamaaarmastusest kannustatud tegelane on ka Martynas Mažvydas näidendis "Mažvydas". Tegemist on 16. sajandil Leedu- ja Preisimaal elanud luteri pastori ja rahvavalgustaja, esimese leedukeelse raamatu, katekismuse (ilmunud 1547) autoriga. Teda piinab pool elu igatsus Leedumaa järele, mida hakkab sümboliseerima koduõele istutatud tamm ning selle sõnaga assotsieeruv mee ja vere maitse suus.

Värssdraama "Katedraal" tutvustab 18. sajandi lõpus Vilniuses tegutsenud rahvuslase ja Vilniuse katedraali arhitekti Laurynas StuokaGucevičiuse (1753-1798) eneseotsinguid kunstnikuna ja vastasseisu 
võimuga. Teose esimene osa käsitlebki leedu kunstnike identiteedi väljakasvamist kuningavõimu ja kiriku teenrite rollist ning teine osa 1794. aasta rahvaülestõusu, mille juhtide sekka Laurynas astub. Tegevustikust olulisemad on siiski poeetilis-filosoofilised mõtisklused inimese ja kunsti kohast ühiskonnas.

Analüüsitud teosed võimaldavad Marcinkevičiust nimetada ka Leedu Shakespeare'iks ning see võrdlus põhjendab osaliselt ka tema tekstide kuulumist vaid Eesti lugemisteatrisse.

\section{Kazys Saja (1932)}

Kõige tuntum leedu näitekirjanik Eestis on kindlasti Kazys Saja. Lihtsa maapoisina üles kasvanud, võrsusid tema teemad ja teosed samuti valdavalt külaühiskonnast ning maaelust. Saja esimene kutselise teatri lavale jõudnud näidend - "Kihlvedu" (Lažybos, 1954, Klaipeda teater) - esietendus juba kaks aastat hiljem ka Eestis, Pärnu draamateatris (lav Artur Ots). Tegemist oli kaasaegse kolhoosikomöödiaga, mida vürtsitasid kupleed ja tantsud (ENSV Töönduskooperatsiooni Kultuuribaasi Pärnu Klubi tantsijate esituses). S. Marvet kiitis oma arvustuses, et suurt rõõmu pakkusid vaatajaile kolm negatiivset laiskurist tegelast: napsulembeline rätsep Domas (Henn Jaaniste), puskariga äritsev põllutööline Veronika (Lia Tarmo) ning seelikukütist ja külaintelligendist arvepidaja Martynas (Paul Ruubel). Positiivsetele tegelastele, sh ka peategelastele heitis ta aga ette verevaesust, kantseliiti ja ideologiseeritust (Marvet 1956). "Kihlveo" tegevuslikus keskmes asuvad nimelt töökad noored - kombainer Ignas (Ilmar Toomla) ja tema abiline Aldona (Õie Maasik) - ning nende vahel puhkenud suur sügav armastus, mida Domase ja Martynase kihlvedu ähvardab nurjata.

Nagu Juhan Smuul Eestis, nii tõi Saja Leedus teatrilavale rahvaliku huumoriga vürtsitatud kaasaegsete lihtsate inimeste elu, ignoreerides sotsialistliku realismi mustvalget tegelassüsteemi ning klassivõitluse kõikeläbistavaid käsulaudu. Samas on tajutav autori mure humanistlike väärtuste allakäigu ning kasuahnuse ja minnalaskmismeeleolude võidutsemise pärast. Sajast kujunes Eestis 1970. aastail väga populaarne autor ning seda eriti väljaspool Tallinna. Järgnev nimekiri kinnitab seda väidet ja annab kronoloogilise ülevaate Saja retseptsioonist Eesti teatris.

"Kihlvedu" (1956, lav Artur Ots, Pärnu draamateater)

"Pühajärv" (1971, lav Grigori Kromanov, Draamateater)

"Polüglott" (1974, lav Gunnar Kilgas, ETV) 
"Puutuvid" (1977, lav Ingo Normet, Pärnu draamateater)

"Klemens" (1978, lav Kaarin Raid, Vanemuine, lavakunstikateedri 8. lennu diplomilavastus)

"Ühepäevaliblikate mäng" pealkirjaga "Naljapäev" (1979, lav Heino Torga ja Felix Šubin, Ugala)

"Hingedevahetus Lohutusmajas" pealkirjaga "Liivakell" (1983, lav Kaarin Raid, Vanemuine)

Saja näidendeid on mängitud üsna aktiivselt ka harrastusteatrites, kuid selle kohta puudub ammendav statistika. Teoste ja tõlgete rohkuse markeerimiseks olgu siiski ära mainitud järgmised: "Rahutus" (1965, Tartu Riikliku Ülikooli klubi näitering), "Päike ja post" (1966, Rahvateater Noorus, 1982, Võru rahvateater), "Maniakk" (1976, Tallinna Pedagoogiline Instituut, 2005, Jõhvi näitetrupp, 2007, Vilde teater), "Abstinent" (1979, Viljandi rajooni kultuurimaja) jt. Lisaks kahele Saja näidendikogumikule, mida tutvustatakse edaspidi, on eesti keeles ilmunud veel argielu- ja suhteprobleeme käsitlevad "Päike ja post” (,Meie repertuaar" 1965, nr 11) ning "Naine lahkub vihmavalingusse" ("Kultuur ja elu" 1970, nr 11).

Järgnevalt vaatlen temaatiliselt Saja tekstide põhjal tehtud lavastusi Eesti kutselistes teatrites ning ka tekste, mis pole lavale jõudnud või on pakkunud huvi ainult asjaarmastajatele.

Saja hakkas ühena esimestest leedu näitekirjanikest kirjutama tinglikke, paradoksaalsetel kujunditel põhinevaid ja absurdielementidega näidendeid. Andres Laasik, tõmmates paralleele Tartust ja Kaunasest kiiranud teatriuuenduste vahel 1960. aastail, toob mh esile ka modernistlike joonte ilmumise eesti ja leedu dramaturgiasse ning mainib leedu modernismi esindusautorina just Sajat, kelle tinglikud lühinäidendid "Maniakk" (1968), "Polüglott" (1969) ja "Abstinent" (1970) ilmusid 1973. aastal Mihkel Looduse tõlkes ka eesti keeles. (Laasik 2005: 41) Nii eesti kirjandus- kui ka teatriväljale jõudsid need tekstid aga väikese hilinemisega, kui teatriuuenduse kõrgaeg oli juba läbi.

"Maniaki" (Maniakas) tegevus toimub suletud ruumis - rongivagunis -, kus püütakse üles leida maniakk. Peaaegu kõik sõitjad mõjuvad kahtlaselt ning osa neist suletaksegi kinnisesse kupeesse. Kuid rong lisab järjest kiirust ning kihutab mööda kõigist jaamadest. Raudteeametnik kinnitab rinda fašistliku märgi ning sunnib reisijaid hirmu peletamiseks laulma. "Maniakki" võib tõlgendada totalitaarse (nii fašistliku, kommunistliku kui ka kapitalistliku) ühiskonna paraboolina ning seeläbi saavutab ta ka nüüdisajal universaalse üldistusjõu. 
"Polüglott" (Poliglotas) on umbes samasugune mudeldraama nagu "Maniakki". See ühevaatuseline tragikomöödia polüglotist professorist esietendus Eesti Televisioonis 1974. aastal Gunnar Kilgase lavastuses. "Polüglotti" võib klassifitseerida eksistentsiaalseks mudeldraamaks, millel on põhimõttelisi sarnasusi nt Paul-Eerik Rummo "Tuhkatriinumänguga" (1969). Nagu Rummo, nii ka Saja näidendis kannavad peategelased üldnimesid: Professor; Naine, keda ta ootas; Naaber. Keskne konflikt "Polüglotis" on üsna lihtne ja universaalne: pensioniikka jõudnud üksik Professor leiab, et teadustööle keskendudes ja eraelust loobudes on ta teinud elus vale valiku. Nüüd ootab ta Naist, keda ta ootas. Mehe korterisse ilmub küll mitmesuguseid naisi, kes kõik ennast talle pakuvad, kuid ükski reaalsetest naistest ei tundu talle õige, vähemalt võrreldes tema kujutlustest sündiva ebamaise Naisega, kellel on samas ilmseid sarnasi professori majapidajannaga. Naaber seevastu on panustanud perekonnale, mis aga ta elu põrguks muudab. Näidend lõpeb Professori kõikehõlmava tõdemusega "Kannatan, järelikult elan" (Saja 1973: 43-44). Polüglotist professor oskab küll kümneid keeli, kuid ei oska rääkida oma ligimestega, ei oska läheduse keelt.

Sirje Endre pidas Gunnar Kilgase lavastust tähelepanuväärseks saavutuseks Eesti teleteatri ajaloos ning eelkõige just kahe meeldejääva rolli, Heino Mandri Professori ja Endel Pärna Naabri pärast. Mandri ei kartnud viia Professori rolli naeruväärsuse viimse piirini, ent see naeruväärsus kulmineerus ülevas traagilisuses. Endel Pärn seevastu mõjus oma rollis jõulisemalt, labasemalt ja küünilisemalt kui Naaber Saja tekstis. Endre küsis, et ehk on elu, mida Naaber elab, lihtsalt kõige halvemaid allaandmise viise. (Endre 1974) Lavastaja oli teinud oma tõlgenduses ka ühe põhimõttelise muudatuse ning valinud ebamaist Naist (Iivi Lepik) ja koduabilist Indulgencijat (Katrin Välbe) kehastama kaks erinevat, peaaegu vastandlikku näitlejannat, rõhutades kujutluse ja iha ning reaalsuse lepitamatut vastuolu.

Ka "Abstinent" ehk "Karsklane" võiks oma alkoholismivastase propagandaga olla aktuaalne 21. sajandi Eesti teatris ja ühiskonnas, kui teksti fiktsionaalne maailm poleks nii tugevalt ankurdatud nõukogude ühiskonda. Nimelt esindab näidendi tegelaskond tüüpilist nõukogude nomenklatuuri, kes uhkeldab võimalustega hankida peeni jooke-sööke, reise läände ning korterit uues kõigi mugavustega majas. Neile vastandub peategelane Vaitasius, kes püüab ülejäänud seltskonnale oma kainusega vastanduda, kuid ei pea ühiskondlikule survele vastu ning sureb alkoholimürgitusse. 
Nagu öeldud, moodustavad domineeriva osa Saja näidenditest siiski Leedu külaelu kujutavad nalja ja lauluga vürtsitatud traagilise alatooniga tekstid. Hea ülevaate tema loomingulisest käekirjast annab Mihkel Looduse tõlgitud kogumik "Leegitsev pirnipuu" (Saja 1983), mis koondab lisaks nimiteosele veel näidendeid "Pühajärv", "Klemens", "Puutuvid" ning "Hingedevahetus Lohutusmajas".

Näidendil "Pühajärv" (Šventežeris, 1970) on ideoloogilisi sarnasusi nii nõukogude eluolu kritiseerivate (Eesti teatris domineeris see suund 1980ndate algul) kui ka tänapäevaste ökokriitiliste (meil üsna marginaalne suund) teostega. Kaunis Pühajärv, mille ääres tegevus toimub, sümboliseerib siin looduse pühadust, mida geoloogid oma puurkaevudega on rüvetanud ning seeläbi rikkunud ka looduse tasakaalu. Kuid Saja ei vastanda omavahel mitte ainult loodust ja tehnoloogiat-tootmist, vaid ka maa- ja linnainimesi. Esimesed kannavad edasi traditsioonilist elulaadi ning väärtusi, teised on aga oma kohatuse (koha puudumise) tõttu moraalselt laostunud (alkoholism, moraalitus, hoolimatus). Teosesse lisab groteski kahe leeri vahel pendeldav Izolda, nn külaullike, kes ei tunne mingeid hea ja halva piire. Ta satub osalema mitmes naturalistlikus stseenis ning vürtsitab konfliktipingeid lorilauludega. Izolda on justkui Leedu külanarr, kes laseb ennast küll narrida, kuid väljub narridest olukordadest ometi alati võitjana. Tema suust kõlab ka näidendi lõpumoraal "Elame veel, Daugviliene, elame veel. Niisamuti nagu pilliroog. Kuhu tuul puhub, sinna pöörame" (Saja 1983: 56).

"Pühajärve" lavastas 1971. aastal Draamateatris Grigori Kromanov ning see pälvis palju ja tunnustavat tähelepanu. ENSV Teatriühingult said aastapreemiad nii lavastaja kui ka kolm näitlejannat: Aino Talvi (Daugviliene), Ita Ever (Izolda) ja Liina Saari (Ramune). Kriitikas arutleti palju tehnilise progressi ja looduskaitse vastasseisu teemadel ning kiideti eelnimetatud rolle. Ü. Taavas [Vambola Rähni pseudonüüm] leidis, et Kromanovi surmtõsine lavastus jagab tegelased liiga lihtsalt kahte lehte ning seepärast mõjub ka lõpplahendus lihtsustatult, justkui probleem oleks vaid geoloogides. Ta väidab, et leedulased ise mängivat seda näidendit komöödiana ning et koomiline element ei tuleks kahjuks ka Tallinna lavastusele. (Järv ja Taavas 1971) Ramune puhul tõstis kriitika esile tema loomulikkust, siirust ja looduslähedust, Daugviliene juures tema traagikat ja elujõudu, Izolde rollist sündis mitu värvikat kirjeldust. Teatrikunstnik Lembit Roosa vastandas esimeses vaatuses mustavad surnud puud vast pestud valgele pesule ning vastukaaluks eelnevale tõi kolmandas vaatuses lavale looduse ilu oma täies tähenduslikus potentsiaalis. (Tobro 1971) 
"Klemens" (Devynbedžiai või Klemensas, 1974), muusikaline mõistulugu kahes osas, sobiks hästi muusikali või ooperi libretoks, sest juba süžees mängivad keskset rolli muusik, muusika ja laulud, süžee meenutab dramaatilist vaatemängulistest stseenidest koosnevat muinasjuttu. Nagu Saja näidenditele iseloomulik, moodustuvad selleski näidendis kaks vastandlikku leeri. Kui alguses on Üheksahäda külas sümboolne võim heitlapsena üles kasvanud muusiku Skalnase käes, siis aegamööda võtab võimu ja koos sellega ka Skalnase armastatu Danute temalt üle noor külavanem Daunoras. Imeliseks abimeheks võimuhaaramisel osutub Klemens, ürgsõnn, kelle võõramaa kaupmeeste laev Üheksahäda külla toob. Mütoloogilised mõõtmed omandanud Klemens hakkab tähistama rikkust ja heaolu. Kahjuks ei salli Klemens muusikat, laulu, tantsu ehk lärmakaid lõbustusi, nii et see tuleb rangelt keelata. Neli aastat hiljem tapab Skalnas sõnni, et anda külarahvale tagasi nende laulud ja rõõmus meel. Just siis, kui tundub, et esialgne kasinusel põhinev harmoonia on külas taastatud, läheneb külale kaupmeeste laev õunikhalli täkuga. Skalnas tormab lõhkuma savipotte, mida külarahvas kasutas kiivrina kaitseks Klemensi vastu, märkamata, et nii piiratakse ka oma (kriitilist) vaatevälja. Seega näib Saja väitvat, et mammona teenimine piirab inimlikku vabadust, nii füüsilist kui ka mentaalset.

Vanemuises lavastas näidendi Kaarin Raid koos lavakunstikateedri 8. lennu üliõpilastega. Erilise mündi andsid lavastusele Urmas Alendri komponeeritud meloodiad ja laulud ning tema enda osalus etendustes. Tiiu Tepandi lava- ja kostüümikujunduses segunesid talupojakultuur linnakultuuri ja fantaasiaga.

Eestis kõige kuulsamaks Saja teoseks võib pidada näidendit "Puutuvid" (Mediniai balandžiai, 1975), sest sellel põhinevast Ingo Normeti lavastusest on tehtud 1979. aastal televersioon, mida on korduvalt ka Eesti Televisioonis näidatud ning kus ansamblis Kuldne Trio kuulsust kogunud Mihkel Smeljanski ja Jüri Vlassov tegid teiste Pärnu näitlejate hulgas huvitavad rollid. Artikli autorile jäi juba lapsepõlvest meelde Uno Uibo lavakujundus, eksootilisena mõjuv leedu puukäsitöö (puuristid, laternad jms) ja puitarhitektuur, rahvalikku muusikasse disharmooniat külvav elektrooniline muusika ning potikedrana pöörlev pöördlava. Nagu eelmine näidend, kujutab ka "Puutuvid" ühe teemana vaese poisi kiiret jõudmist haljale oksale. Kuid rikastumine vahendeid valimata Leonasele (Smeljanski) õnne ei too. Teose alguses jääb mulje, et tegemist on melo- või saatusedraamaga, kus Leonase hüljatud armastatu (Lii Tedre) ja tapetud laps talle kätte maksavad, kuid see mulje on ekslik, sest Sajat näib üksikisikutest rohkem huvitavat see heas ja halvas 
kokku hoidev külaühiskond. Praktiline mõistus ja südameheadus aitab selle kogukonna suuremate kaotusteta läbi ka segastest sõjaaegadest. Teise osa keskmesse on Saja toonud hoopis juudi tüdruku Judita (Helle Kuningas), kes end fašistide eest samas külas peidab. Tundeinimesest vastu tahtmist praktiliseks perenaiseks hakanud Terese (Tedre) saab aga küüraka Küürukesega (Vlassov) kuus last.

"Puutuvid" pälvis mitu preemiat: lavastaja Ingo Normet üleliidulise festivali vabariikliku vooru laureaadi tiitli ja II preemia, kunstnik Uno Uibo I preemia, Jüri Vlassovi roll II preemia ning esile tõsteti ka Mihkel Smeljanskit. "Vlassovi Küüruke on "Puutuvide" soojuskiirguse tundlik näitaja, lavastusmõtte kvintessents." (Laid 1977) Seda ideed kandsid lavastuses ka Küürukese meisterdatud värvilised mänguasjad - puutuvid, rahuidee maalähedased representatsioonid.

Lavastamatajäi Eestis samanimelises kogumikus avaldatud "Leegitsev pirnipuu" (Liepsnojanti kriaušé, 1977), kus on äratuntavalt esitatud Saja lemmikteemad: demoraliseeriv materialistlik nõukogude ühiskond ning sellele vastukaaluks seatud traditsiooniline eluviis ning folkloor. Kuid selle näidendi teevad huvitavaks peategelase Elena madiskõivulikud nägemused, kus surnud räägivad vaheldumisi elavatega ning kus sünnib tugevaid visuaalseid metafoore. Näiteks oma mehe surma näeb/tõlgendab ta niimoodi: "Kui lava valgeneb, seisavad B u rb a ja B i v a in is keset tuba ja hoiavad raami, mille sees on uks. Siinpool suletud ust seisab E le na. Tema ettesirutatud kätel on viht punast lõnga. Lõng läheb läbi ukse lukuaugu, ukse taga seisva [surnud - A. S.] Van a e m a n i, kes kerib lõnga kerasse ja vestab edasi oma poolelijäänud muinasjuttu." (Saja 1983: 184) Elena on pärimust hoidev vana maanaine, kunstnik, kes maalib kirglikult naivistlikke teoseid, milles tema reaalne elu seguneb mälestuste ja/või ettekuulutustega. Just nimelt side eelkäijate, surnud sugulastega seob tema maailma tervikuks ning paneb aluse harmoonilisele elule. Elena kolm täiskasvanud tütart lähtuvad rohkem materiaalsetest väärtustest, mis satuvad vastuollu humanistliku eetikaga, ning peavad ema kunstiharrastust haiguseks. Näidend lõpebki sellega, et tütarde pealekäimisel on ema terveks ravitud ehk temast on saanud tavaline nõukogude inimene - asjalik sanitar. Leegitsev pirnipuu teose pealkirjas viitab aga Elena räägitud mõistuloole tagakiusatud pirnipuust, mis pikselt halastust palus ning mille pikne alles siis põlema süüdata sai, kui see teistest puudest pikemaks oli kasvanud. Selles animistlikus paraboolis võib näha otseseid paralleele kristliku passiooniga.

"Ühepäevaliblikate mäng" esietendus 1979. aastal Ugala teatris pealkirjaga "Naljapäev”(lav Heino Torga ja Felix Šubin). Selle näi- 
dendi ja lavastuste kohta käiv info on üsna napp. Ugala kirjandusala juhataja Šubin tutvustas "Naljapäeva" toona nii: "1. aprill on naljapäev, ainus ja tõeline pidupäev selle komöödia tegelaste jaoks. Nad aimavad ja valmistavad ette seda päeva, mil avanevad nende elu liblikatiivad, et siis teha nalja, pilada kõike, mis ette juhtub. Nad armastavad, vihkavad, usuvad, petavad, abielluvad, lahutavad, töötavad, laisklevad - mängeldes, sest mäng on muutunud nende elu mõtteks.” (Šubin 1979)

Eelmistest teostest mõnevõrra erinev on näidend "Hingedevahetus Lohutusmajas" (1981), sest kuigi autor on tegevuse paigutanud oma kaasaega ja planeedile Maa ning samas andnud teosele žanrimääratluse "ulmeline melodraama", võib seda tingliku aegruumi ja filosofeerivate tegelastega teost klassifitseerida Saja teiste eksistentsialistlike mudeldraamade hulka. Lohutusmajaks nimetatakse vanasse lossi rajatud kliinikut, kus doktor Novat pakub enesetappu plaanivatele klientidele võimalust vahetada oma hing ja elu mõne teise selle maja kliendi omadega. Lugeja-vaataja saab kaasa elada erinevate tegelaste rollivahetusdilemmadele: kas ja kellega üldse tasub ära vahetada oma elu - õnnetu küll, aga siiski oma. Lõpuks selgub, et sajast enesetapjast pole keegi seni veel sellele liimile läinud ning paljud on selle asemel leidnud oma kutsumuse teiste õnnetute inimeste aitamises. Seega teose sõnum on küll selge, kuid psühholoogiliselt tunduvad tegelaste äkilised armumised ning meelemuutused siiski ebausutavad. Samas ei tohi alahinnata teoses esitatud mõttemängu teraapilist mõju.

Evald Kampus (1983) tutvustas teost Vanemuise esietenduse eel realistlikust paradigmast lähtuvalt: "Tegevuspaigaks võib kujutada mingit Lääne ultramoodsat linna koos heategevusasutuste, psühhoteraapiakatsete ja šarlatansusega." Kriitikud heitsid Kaarin Raidi lavastusele ette ebaühtlust ja autoripositsiooni ebamäärasusust. Leiti, et võrdluses vahetult enne "Liivakella" esietendunud ja temaatiliselt sarnase Luigi Pirandello teosega "Heinrich IV" jääb Saja tekst tiheduselt alla. Etteheiteid jagus ka Vanemuise näitlejatele, kes jäid kinni oma tuttavatesse stampidesse ning kippusid üksteist "surnuks mängima" (Türn ja Ojar 1983).

Kazys Saja näidendid on andnud tähelepanuvärse panuse Eesti teatrite repertuaari. Eriti on siinseid teatritegijaid võlunud Saja eksistentsialistliku alltekstiga kujundirohked tekstid, millel pole tugevaid rahvusliku kultuuri markereid. 


\section{Marius Ivaškevičius (1973)}

Marius Ivaškevičius on ilmselt kõige kuulsam ja skandaalsem 21. sajandi Leedu (näite)kirjanik, kes oskab mängida leedukatele helladel teemadel. Näiteks naeruvääristas tema näidend "Madagaskar" (2004, lav Rimas Tuminas, Väike Teater) leedu rahvuslikku ideoloogiat ja suurkujusid. Mitu oma teksti on ta ise lavale toonud ning aastast 2007 tegutseb ta filmirežissöörina.

Ivaškevičius üllatas Eesti publikut oma näidendiga "Väljaheitmine. Ühe ouna kroonika" (Išvarymas. Vieno obuolio kronika, 2011, tlk Tiiu Sandrak), mille Hendrik Toompere jr lavastas aastal 2016 Eesti Draamateatris. Üllatas, sest kuigi ka Eesti oli seisnud silmitsi massilise väljarändega, olid selle teema kunstilised käsitlused olnud kas kurbkoomilised ja musta huumori võtmes (nt teleseriaal "Kalevipojad", stsenarist Martin Algus, rež Ergo Kuld, 2011, Kanal 2) või dokumenteerivad-lepitavad (nt teatrilavastus "45 $339 \mathrm{~km}^{2}$ raba", autorid Andra Teede ja Laura Mets, 2015, Endla).

"Väljaheitmine" eristub eelnimetatutest eepilisuse ja eksistentsiaalse mõõtmega. Endine kriminaalpolitseinik, rassistlike ja homofoobsete kalduvustega Ben (Kristo Viiding) jutustab oma Inglismaale saabumise ja immigrandieluga kohanemise loo. Õuna kujund näidendi pealkirjas pärineb nn inimsmugeldajate slängist, kus värskelt maale toodud inimesi nimetatakse ounteks. Kuid oma 12 aastat kestnud odysseuslike eksirännakutega seoses maalib ta ka karakteerseid portreid erinevatest Leedu või üldisemalt immigranditüüpidest. Siin on vene verd kantpea Vandaal (Nikolai Bentsler), kelle jaoks õnn seisneb vaid vaikses nurgakeses ja valges viinas, skvotteritest anarhistid Olga (Liisa Saaremäel) ja Karlis (Christopher Rajaveer), vähenõudlik ja ambitsioonitu pardikorjaja Eddy (eestipäraselt Eedi - Markus Luik), luhtunud kunstnikuambitsioonidega lõbutüdruk ja hilisem mosleminaine Migle (Egle - Inga Salurand) jt. Ben läbib peaaegu kõik immigrandielu faasid, alustades passivargusest, petta ja peksa saamisest ning muudest paadiehk sillaaluse elu "hüvedest" ning liikudes eluruumidest või mentaalsetest paradiisidest väljaheitmistest hoolimata vaikselt elu edetabelis ülespoole, kuni jõuab taas politseiniku auväärse ametikohani. Lisaks sellele on tema britist tüdruksõber ja töökaaslane Liz (Elizabeth Harriet Toompere) lapseootele jäänud. Ben, nüüd nimega Bobby, on oma identiteeti Lizi eest varjanud, kuid kohtumised vanade tuttavatega paljastavad ta - oodata on uut Paradiisist väljaheitmist. Näidend lõpeb siiski lepitavalt: Ben lepib nii oma kauaaegse vihavaenlase, teda peksnud britiga kui ka inimelu ühe põhiatribuudi - väljaheitmisega. 
Kuigi "Väljaheitmise" lavastus Leedus tekitas alguses suure skandaali, eelkõige ebatsensuurse sõnakasutuse ja tundliku temaatika tõttu, on nii tekst kui ka selle lavastused Vilniuses, Riias ja Tallinnas sotsiaalselt funktsioonilt samuti lepitavad. Käsitletakse küll emigratsiooni kui riiklikult ja rahvuslikult teravat probleemi kõigis Baltimaades ning immigrandi rusuvat enese- ja elutunnetust uuel kodumaal, kuid seda tehakse humoorikalt ning peaaegu muusikali võtmes.

\section{Kokkuvõtteks}

Eesti keeles on välja antud ning Eesti kutselistes teatrites lavastatud 20 leedu näidendit, kuid need kategooriad kattuvad üksteisega vaid osaliselt. Leedu keelest eesti keelde tõlgitud näidendite hulk on suurem, kui artiklis käsitletud, ulatudes umbes 40-ni. Leedu kirjanduse, sh näitekirjanduse eesti keelde vahendamine on suures osas olnud ühe tõlkija - Mihkel Looduse - missioon. Loodus on tõlkinud 27 leedu autori näidendit (Leedu... 2013).

Lõpetuseks tuleb küsida seda, mida oleks pidanud küsima juba alustuseks: mis on Eestil Leedust või Leedu näitekirjandusest?

Esiteks, kuna eesti näitekirjandus ning tegelikult isegi mitte dramaatiline proosa ei suuda rahuldada kõigi kohalike teatrite pidevat vajadust uute või unustusse vajunud tekstide järele, siis on suurem osa repertuaarist läbi aegade tuginenud tõlkekirjandusele. Kui näidendeid juba peab eesti keelde tõlkima, siis miks mitte võimalikult laiast kultuurilisest ringist, kuhu kindlasti võiksid kuuluda ka läti ja leedu kirjandus, eeldusel, et neil on pakkuda midagi omapärast vastukaaluks nüüdisteatris domineerivale angloameerika näitekirjandusele.

Lisaks eelnimetatud pragmaatilisele põhjusele tuleks välja tuua ka sotsiaalpoliitiline argument. Nimelt on üheks lähinaabritega kultuurisidemete arendamise põhjuseks alati olnud ka rahu ja koostöö tagamine või sillutamine. Kultuur on nagu õli äri ja poliitiliste sidemete toimimiseks.

Ning lõpetuseks kõige olulisem, esteetilis-eksistentsiaalne argument. Kunst on alati aidanud mõtestada inimeksistentsi alusprintsiipe, visandanud olemisvõimalusi, tutvustanud ja selgitanud erinevaid väärtushinnanguid. Leedu dramaturgia on pakkunud eesti näitlejatele materjali mitmeplaaniliste rollide loomiseks ning lugejatele-vaatajatele eelkõige äratundmisrõõmu ja hingetuge traditsioonilise kultuuri ja humanistlike väärtuste hoidmisel. Kuid samavõrra on leedu draama toonud esile ka erinevusi, eriti just draamatehnilises vallas, mis eesti kultuuri ja eestlaste maailmapilti kindlasti rikastavad. Vaid võõra silmades näed sa 
iseennast - see kehtib nii rahvuse kui üksikisiku kohta. Ning ümberpöördult - "Võib inimlaps teist inimlast vaid mõista / ja üksnes niivõrd, kuivõrd mõistab ennast" (Marcinkevičius 1980: 10).

Märkus: Selle artikli valmimist on toetanud Euroopa Liit Euroopa Regionaalarengu Fondi kaudu (Eesti-uuringute tippkeskus), see on seotud Eesti Haridus- ja Teadusministeeriumi uurimisprojektiga PUT 192 ("Esilduvad lood: jutustamine ja ühine tähendusloome narratiivses keskkonnas").

\author{
Aadress: \\ Anneli Saro \\ Kultuuriteaduste ja kunstide instituut \\ Tartu Ülikool \\ Ülikooli 16 \\ 51014 Tartu, Eesti \\ E-post: anneli.saro@ut.ee
}

\title{
Kirjandus
}

Allik, Jaak (2006) “Kas Balti teatrifestival jääb kestma?”. Sirp, 15.09.

Eesti sõnateater 1965-1985. I köide. Teatriprotsess: taustad, ilmingud, peegeldused. Lavastajaportreed (2015) Tallinn: Eesti Muusika- ja Teatriakadeemia lavakunstikool, Eesti Teatriliit, Eesti TA Underi ja Tuglase Kirjanduskeskus.

Eesti Teatri Agentuuri näidendite andmebaas. Leedu näidendid. $<$ http://www.teater. ee/naidendid/andmebaas/?_page $=1 \&$ _count_all=39\&country $=$ Leedu $>$. Vaadatud 09.02.2017.

Endre, Sirje (1974) "Televisiooniteatrist, seal toimuvast, eriti "Polüglotist"'. Edasi, 03.03.

Gerlach, Klaus, Harry Liivrand ja Kristel Pappel, toim (2016) August von Kotzebue im estnisch-deutschen Dialog. Hannover: Wehrhahn Verlag; Berlin-Brandenburgische Akademie der Wissenschaften.

Grušas, Juozas (1987) Näidendid. Tallinn: Eesti Raamat.

Ivaškevičius, Marius (2015) Väljaheitmine. Ühe õuna kroonika. Käsikiri. Tallinn: Eesti Draamateater.

Järv, Ants ja Ü. Taavas (1971) “Draamateatri augustihooaeg”. Edasi, 29.08.

Kask, Karin (1987) Eesti nõukogude teater, 1940-1965. Sõnalavastus. Tallinn: Eesti Raamat.

Kask, Karin (1964) Shakespeare Eesti teatris. Tallinn: Eesti Riiklik Kirjastus.

Kampus, Evald (1983) “Hooaja viimane esietendus”. Edasi, 18.06. 
Kuidas päikest sõelaga tehti ehk Kuidas "Vanemuises" möödunud aastasajal rahva rõõmuks ja kasuks näitemängu mängiti (1974) Koost Lilian Kirepe. Tallinn: Eesti NSV Kultuuriministeerium, Teatri- ja Muusikamuuseum.

Laasik, Andres (2005) Kaks teatriutoopiat. 1960. ja 1970. aastate teatriuuendus Eestis ja Soomes - kaks paralleelset kultuuriilmingut. Käsikirjaline magistritöö Tartu Ülikooli kultuuriteaduste ja kunstide instituudis.

Laid, Eero (1977) ““'Puutuvid” Pärnu teatris”. Sirp ja Vasar, 25.11.

Leedu kirjanduse tõlkijate aastapreemia Mihkel Loodusele (2013) Sirp, 1.10.

Levin, Sergei (1970) "S pozicij voinstvujuščego gumanizma". Sovetskaja Estonija, 25.01

Lithuanian Theatre (2009) Vilnius: Culture, Philosophy and Arts Research Institute.

Marcinkevičius, Justinas (1980) Katedraal. Draama 10 laulus. Tallinn: Eesti Raamat.

Marcinkevičius, Justinas (1988) Mindaugas. Draamapoeem 2 osas. Tallinn: Eesti Raamat.

Marcinkevičius, Justinas (1991) Mažvydas. Värssdraama. Tallinn: Eesti Raamat.

Marcinkevičius, Justinas (2016) Heroica, ehk, Prometheuse hukkamoist. Võru: Hilanamoro.

Marvet, S. (1956) "Vaadates hooaja avaetendusi. "Kihlvedu"'. Pärnu Kommunist, 20.10.

Mikalauskaite, Regina (1964) Pruut. Kuuldemäng. <https://arhiiv.err.ee/vaata/kuuldemang-kuuldemang-pruut $>$. Vaadatud 09.02.2017.

Miliūnas, Viktoras (1955) Allamäge. Tallinn: Eesti Ajalehtede-Ajakirjade Kirjastus.

Pappel, Kristel (2003) Ooper Tallinnas 19. sajandil. Tallinn: Eesti Muusikaakadeemia.

Puutuvid. Telelavastus. $<$ https://arhiiv.err.ee/seeria/puutuvid/lavastuslik/31>.

Vaadatud 09.02.2017.

Rämmer, Algo (2016) Haritlased ja Balti kultuurikoostöö 1920.-1930. aastatel. (Dissertationes historiae Universitatis Tartuensis 40.) Tartu: Tartu Ülikooli Kirjastus.

Saja, Kazys (1973) Polüglott. Abstinent. Maniakk. Loomingu Raamatukogu 31-32. Tallinn: Perioodika.

Saja, Kazys (1983) Leegitsev pirnipuu. Näidendid. Tallinn: Eesti Raamat.

Saro, Anneli (2004) Madis Kõivu näidendite teatriretseptsioon. (Dissertationes litterarum et contemplationis comparativae Universitatis Tartuensis.) Tartu: Tartu Ülikooli Kirjastus.

Šubin, F. (1979) ““'Ugala“ tuleb külla”. Koit, 24.03.

Tamm, J. (1960) "Valvsusele kutsuv lavateos". Tee Kommunismile, 6.02.

Tobro, Valdeko (1971) ““"Pühajärv” Draamateatris”. Sirp ja Vasar, 14.05.

Tormis, Lea (1978) Eesti teater 1920-1940. Sõnalavastus. Tallinn: Eesti Raamat.

Tormis, Lea (1973) Teatrisuhted üle idapiiri. Eesti teatri sidemetest nõukogude teatriga 1920-1940. Tallinn: Eesti Raamat.

Türn, Marika ja Eduard Ojar (1983) “Kaks arvamust “Liivakellast””. Edasi, 10.07. 


\begin{abstract}
Anneli Saro: Reception of Lithuanian drama in Estonia. The article has two aims: (1) to give a statistical overview of Lithuanian drama published and staged in Estonia, and (2) to investigate the reception of Lithuanian drama in Estonia, relying on close reading of the plays and analysis of audiovisual recordings and criticism, and interpreting the sources in the Estonian cultural context. The term "reception" here covers the creative work of translators, directors, actors, scenographers, etc., as well as diverse mental activities of readers and spectators.

The first part of the article tackles the historical development of cultural relations between Estonia and Lithuania in the field of theatre, listing the Lithuanian plays published and staged in Estonia during different epochs and contextualizing the reception. In the second part, the plays of four influential playwrights are analyzed: works by Juozas Grušas, Kazys Saja, Justinas Marcinkevičius and Marius Ivaškevičius.

There are approximately forty Lithuanian plays translated into Estonian, most of them by Mihkel Loodus. Twenty plays have been staged in professional theatres, and twenty have been published, although some are still in manuscript. There are three groups of plays translated into Estonian: (1) plays depicting Soviet society, staged in Estonia in the second half of the 1950s and in the first half of the 1960s, 2) plays depicting Lithuanian history, mostly published as books, and 3) existential plays that form the majority of Lithuanian drama in Estonian.
\end{abstract}

Keywords: Lithuanian drama, Estonian theatre, reception, cultural relations between Estonia and Lithuania 